
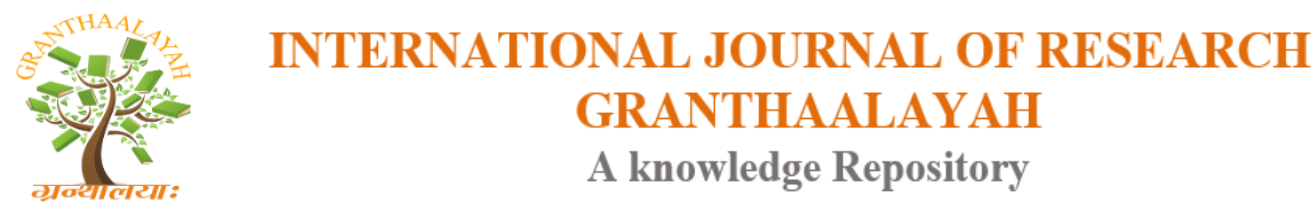

Science

\title{
WOMEN PROPOSITION IN THE INDIAN JUDICIARY
}

\author{
Bipasha Bandopadhyay *1 \\ ${ }^{* 1}$ Law Department, Indore Institute of Law, India
}

\begin{abstract}
There have been innumerable debates about gender in India over the years. Much of it includes women's positing in society, their education, health, economic position, gender equality etc. What one can conclude from such discussions is that women have always held a certain paradoxical position in our developing country.

The women position in Indian Judiciary has again been a debatable, topic which has henceforth never been into exact numerical representation. The women clan involved into the legal network of benches has been notably less. The women position has been the highest in the Supreme Court of India with 'Nine' Judges.

The research work includes statistical data with the research of Vidhi legal policy. "The District Courts and the courts below them comprise the 'lower' or 'subordinate' judiciary. These courts lie under the administrative control of High Courts. Each judicial district in India has one District Court, below which lie civil and criminal courts of original jurisdiction," the study notes, and finds that $71 \%$ judges in the subordinate judiciary across India are male.

Motivation/Background: The women position has been the highest in the Supreme Court of India with 'Nine' Judges. The women clan involved into the legal network of benches has been notably less.
\end{abstract}

Method: The fundamental protestant of the research are 'women', their count in the benches of Indian Judiciary, specifically over the High Courts and the Supreme Court. So what has been the reason behind such a low count of women?

What has been the numerical denomination of women benches in High Courts and Supreme Courts over the past years?

Results: Women were relegated to the household, and made to submit to the male-dominated patriarchal society, as has always been prevalent in our country. Indian women, who fought as equals with men in the nationalist struggle, were not given that free public space anymore. They became homemakers, and were mainly meant to build a strong home to support their men who were to build the newly independent country.

Conclusions: Women were reduced to being second class citizens. The national female literacy rate was an alarmingly low 8.6\%. The Gross Enrolment Ratio (GER) for girls was $24.8 \%$ at primary level and $4.6 \%$ at the upper primary level (in the 11-14 years age group). There existed insoluble social and cultural barriers to education of women and access to organized schooling.

Keywords: Law Ministry Reports; Judiciary; Bench; High Court; Supreme Court. 
Cite This Article: Bipasha Bandopadhyay. (2018). "WOMEN PROPOSITION IN THE INDIAN JUDICIARY." International Journal of Research - Granthaalayah, 6(8), 114-129. https://doi.org/10.29121/granthaalayah.v6.i8.2018.1405.

\section{Introduction}

\section{Research Aim}

The aim of the work and the overall purpose of the study is to appraise the count of women in legal fraternity. To succinct the research domain, the research intents to lay precise data about the female position in Indian Judiciary. The research paper assembles and addresses the numerical representation of women in Indian High Courts and Supreme Court, i.e. they reflect the aspirations and expectations of the research topic.

\section{Scope of Research}

The scope of the research topic includes the study of the women proposition in the Indian Judiciary and to re-assess the reasons behind such low numeral of women position in Indian Benches.

\section{Objective of the Study}

The below listed objectives are deduced from the research questions in order to have comprehensive answers to them.

- To reconnoiter the female legacy in Indian judiciary.

- To diagnose the reason behind such less number of female participation in the legal clan.

- To trace the changing trend of feminine contribution in Indian judiciary.

- To critically analyze the women locus in Indian Judiciary during the present era.

- To establish the numerical figures of women sharing in Indian Judiciary.

- To evaluate the numerical figures of women sharing in Indian Judiciary.

- To scrutinize the growth or shrinking of women clan in Indian benches.

- To find out the present drift of women involvement in Indian Courts.

\section{Background}

The archetypal specimen of women in judiciary heeds back to the Greek and Roman lore. Goddess Themis, one of the wives of Zeus, was the Greek Goddess of Justice and she was considered the epitome of divine order, law, and custom. Dike and Astrea were her two daughters who were also considered as Godesses of Justice and have often been depicted as carrying scales in poetry and mythology. Of a later origin is Justitia or Lady Justice, who was the Roman Goddess of Justice.

Justitia is most often portrayed with a set of scales classically suspended from her left hand, upon which she measures the fortes of a case's support and opposition. She is often seen carrying a double-edged sword in her right hand, embodying the power of Reason and Justice, which may be wielded either for or against any party.

It is thought-provoking to see that even modern day depictions of justice in courts all around the globe is of a lady justice carrying a sword and scales, who is often blindfolded to symbolize the fair and equal administration of the law, without corruption, avarice, prejudice, or favor. 
We have not followed the practice of having the iconography of the Lady Justice with scales in our courtrooms, but if we revisit Indian mythology, it mentions the goddess Bagla Mukhi Devi enshrined at Pitambara Peeth situated in Datia town near the city of Gwalior in Madhya Pradesh. As per the local folk lore, the blessings of this deity are especially solicited by those in the judicial stream to deliver justice in a free and fair manner.

It may also be of interest to some that our Supreme Court building was designed by the architects in a shape to project the image of scales of justice with the Central Wing of the building corresponding to the centre beam of the Scales. It appears that the scales of justice embodied in the architecture of the highest court of justice in India, are none other than those that Lady Justice holds in her hands.

Hence, it would be reasonably safe to assume that the presence of lady judges in Indian Courts runs far and deep.

Coming back to women in flesh and blood, the first woman to be appointed to the Supreme Court was Justice Fatima Beevi in 1987. She was later followed by the appointment of Justice Sujata Manohar in the year 1994 and Justice Ruma Pal in the year 2000. As of now, we have only woman judge in the Supreme Court, i.e., Justice Gyan Sudha Misra. There are around 52 women judges gracing the benches in the High Courts all over the country, out of which 7 are in our own High Court at Delhi.

Statistics reveal that as on date, there are around 45 women in the Delhi Higher Judicial Service and 91 in the Delhi Judicial Service, which makes it $29 \%$ of the 'in position strength' of both the cadres collectively. While no discernible trend in respect of gender justice can be ascertained from the judgments delivered by the four women judges in the Supreme Court, it cannot be denied that there are some instances where path breaking concepts in women's rights have been addressed by benches of which they were a part. Justice Sujata Manohar was part of the three-judge bench in the landmark case of Vishaka, where for the first time the sensitive and increasingly common problem of sexual harassment at the workplace was dealt with. It would be safe to assume that a significant contribution must have been made by her in helping her brother judges in developing an understanding of an area of law which was res integral and till then had been neglected by the parliamentarians, as no statutory law for the penalization of sexual harassment at the work place existed at that time.

Similarly, Justice Ruma Pal, often considered a tough as-nails judge, through her judgments in A. Jayachandra and Vinita Saxena, extensively elaborated on the concepts of 'mental cruelty' in a marriage and 'cruelty as a ground for divorce'. Another significant contribution made by her was in the case of R.D. Upadhyaya, while dealing with the sensitive issue of the welfare of children of women undertrials and women convicts, often forced to live with their mothers in the prison.

From all this, one can gather that when faced with a case of say rape, or cruelty in marriage, etc. women judges are likely to deal with them in the same manner as a fellow brother judge, yet when faced with a hitherto unexplored area of law, especially where gender justice is concerned, they wouldn't hesitate to stray from the conventional path. As a woman and a judge, I think any 
initiative taken to improve the status of women in society, be it by a male judge or a female judge, must be appreciated and applauded.

Adding another dimension to the women in judiciary are the Mahila Courts. In Delhi, Mahila Courts were established in 1994, and at present there are 11 Mahila Courts functioning in the capital. At the session level, Mahila Courts deal with cases of kidnapping, procuring minor girls for the purpose of prostitution, rape and of cruelty by husbands or in-laws. The metropolitan magistrates in these courts are assigned cases relating to molestation, rape, kidnapping, as also of domestic violence. These are courts that truly deal with persons living on the margins of the society and the women judges manning them are the foot soldiers who play a pivotal role in the judicial delivery mechanism at the lowest level. These brave women, who sit day in and day out, and hear cases of abuse and severe mistreatment, and to their credit, do not allow themselves to be prejudiced while attempting to do justice in the most neutral and unpartisan manner, are rendering yeoman service to the institution. ${ }^{1}$

\section{Law Ministry Reports}

Table: $1^{2}$

\begin{tabular}{|l|l|l|}
\hline Groups & Department of Legal Affairs (Including Legislative Department) \\
\hline Group A & 97 & 15 \\
\hline Group B & 250 & 93 \\
\hline Group C & 135 & 4 \\
\hline Group D & 172 & 15 \\
\hline Total & 654 & 127 \\
\hline
\end{tabular}

Representation of Female Employees in Legislative Department (As On 01-01-2017)

Table: $2^{3}$

\begin{tabular}{|l|l|l|l|}
\hline GROUP & Total No. of Employees & No. of Female Employees & $\begin{array}{l}\text { Percentage } \\
(\boldsymbol{\%})\end{array}$ \\
\hline GROUP 'A' & 70 & 15 & 21.4 \\
\hline GROUP 'B' & 110 & 34 & 30.9 \\
\hline GROUP 'C' & 114 & 12 & 10.5 \\
\hline TOTAL & 294 & 61 & 20.7 \\
\hline
\end{tabular}

\section{Numerical Figure of Female Judges in India}

\subsection{Female Judges of the Supreme Court of India}

In the walk of 71 years of Indian Independence, the apex court, the Supreme Court of India has crowned only 7 female Judges. The Supreme Court collegium has recommended the name of senior advocate Indu Malhotra as the first woman lawyer to be unswervingly appointed as a judge of the apex court, Supreme Court of India. 
End to end, Uttarakhand High Court Chief Justice K.M. Joseph, who was part of the bench which in 2016 had quashed the imposition of president's rule in the state, has also been cleared for elevation to the apex court.

At a meeting held on January 10, the collegium also recommended the name of Justice Sheo Kumar Singh-I, presently an additional judge, for appointment as a permanent judge of the Allahabad High Court.

Justice Joseph was appointed as permanent judge of the Kerala high court in 2004 and later reassigned to Uttarakhand high court where he anticipated charge in 2014 as chief justice.

Malhotra, who was nominated as a senior advocate in 2007, would be the first woman lawyer to be directly appointed as a judge of the top court, instead of being preeminent from a high court.

She will be the seventh woman judge since independence to make it to the Supreme Court. At present, Justice R. Banumathi is the unique woman judge in the apex court.

Since Independence, only six women judges have made it to the apex court as judges and the first appointment was of Justice M. Fathima Beevi in 1989, 39 years after the setting up of the Supreme Court in 1950.

Justice Fathima Beevi was raised to the apex court after her retirement as judge of the Kerala high court. After aiding the top court till April 29, 1992, she was later selected as the governor of Tamil Nadu.

The subsequent woman judge in the Supreme Court was Justice Sujata V. Manohar who started her profession as a judge from the Bombay high court and rose to become the Chief Justice of the Kerala high court. She was elevated to the apex court where she remained from November 8, 1994 till August 27, 1999.

Justice Ruma Pal followed Manohar after a gap of almost five months and became the longestserving woman judge from January 28, 2000 to June 2, 2006.

After her retirement, it took four years to employ the next woman judge. Justice Gyan Sudha Misra was elevated to the Supreme Court from the Jharkhand high court where she was the chief justice. Her tenure in the apex court was from April 30, 2010 to April 27, 2014.

During her stint, she was joined by Justice Ranjana Prakash Desai, who served the apex court between September13, 2011 to October29, 2014. These two judges also created a history by holding the court together as an all-women bench for a day in 2013.

Justice Banumathi, who at present is the only sitting woman judge, had joined on August 13, 2014 and would retire on July 19, 2020. 
In the 67-year history of the Supreme Court, there have been only two occasions when it has had two sitting women judges together, the first being Justices Misra and Desai and later Justices Desai and Banumathi.

The collegium is headed by Chief Justice Dipak Misra and has the four senior-most judges of the apex court - Justices J Chelameswar, Ranjan Gogoi, Madan B Lokur and Kurian Joseph - as its other members. ${ }^{4}$

\subsubsection{Count of Female Judges at the Supreme Court of India}

Table 3: clearly shows that there have been only 'Seven' female judges in the Supreme Court of

\begin{tabular}{|l|l|l|l|l|}
\hline $\begin{array}{c}\text { Sr. } \\
\text { No. }\end{array}$ & \multicolumn{1}{|c|}{ Name } & \multicolumn{1}{|c|}{$\begin{array}{c}\text { Date of } \\
\text { appointment }\end{array}$} & $\begin{array}{c}\text { Date of } \\
\text { retirement }\end{array}$ & $\begin{array}{c}\text { State/union } \\
\text { territory }\end{array}$ \\
\hline $\mathbf{1}$ & $\begin{array}{l}\text { Fathima Beevi } \\
\left(1^{\text {st }} \text { Female Judge of }\right. \\
\text { Supreme court })\end{array}$ & October 61989 & April 291992 & Kerala \\
\hline $\mathbf{2}$ & Sujata V. Manohar & November 81994 & August 27 1999 & Maharashtra \\
\hline $\mathbf{3}$ & Ruma Pal & January 28 2000 & June 2 2006 & Calcutta \\
\hline $\mathbf{4}$ & Gyan Sudha Misra & April 30 2010 & April 27 2014 & Jharkhand \\
\hline $\mathbf{5}$ & Ranjana Prakash Desai & September 132011 & $\begin{array}{l}\text { October } 29 \\
2014\end{array}$ & Bombay \\
\hline $\mathbf{6}$ & R. Banumathi & August 13 2014 & July 19 2020 & Delhi \\
\hline $\mathbf{7}$ & Indu Malhotra & April 27 2018 & April 23 2021 & Delhi \\
\hline
\end{tabular}

\subsection{Female Judges of the High Courts of India}

\section{Allahabad High Court}

(List of Female Judges Arranged According to Date of Initial Appointment)

Table 4: Projects the cumulative number of female judges at 'Allahabad High Court' as 'Six' in figure. $^{6}$

\begin{tabular}{|l|l|l|l|l|l|}
\hline $\begin{array}{c}\text { SI. } \\
\text { No. }\end{array}$ & Name of the judge & $\begin{array}{c}\text { Source of } \\
\text { recruitment }\end{array}$ & $\begin{array}{c}\text { Date of } \\
\text { appointment } \\
\text { as addl. Judge }\end{array}$ & $\begin{array}{c}\text { Date of } \\
\text { appointment } \\
\text { as pmt. Judge }\end{array}$ & $\begin{array}{c}\text { Date of } \\
\text { retirement }\end{array}$ \\
\hline 1. & $\begin{array}{l}\text { Kumari Bharati } \\
\text { Sapru }\end{array}$ & Bar & $05 / 10 / 2005$ & $10 / 08 / 2007$ & $28 / 07 / 2020$ \\
\hline 2. & $\begin{array}{l}\text { Kumari Naheed Ara } \\
\text { Moonis }\end{array}$ & Bar & $13 / 04 / 2009$ & $24 / 12 / 2010$ & $07 / 12 / 2021$ \\
\hline 3. & Smt. Sunita Agarwal & Bar & $21 / 11 / 2011$ & $06 / 08 / 2013$ & $29 / 04 / 2028$ \\
\hline 4. & Smt. Vijay Lakshmi & Service & $03 / 02 / 2014$ & $01 / 02 / 2016$ & $28 / 10 / 2018$ \\
\hline 5. & $\begin{array}{l}\text { Smt. Sangeeta } \\
\text { Chandra }\end{array}$ & Bar & $15 / 11 / 2016$ & $23 / 03 / 2018$ & $22 / 04 / 2030$ \\
\hline 6. & Smt. Rekha Dikshit & Service & $15 / 11 / 2016$ & $23 / 03 / 2018$ & $09 / 08 / 2021$ \\
\hline
\end{tabular}




\section{Telangana \& Andhra Pradesh High Court}

(List of Female Judges Arranged According to Date of Initial Appointment)

Table 5: projects the cumulative number of female judges at 'Telangana \& Andhra Pradesh High Court' as 'Three' in figure.

\begin{tabular}{|l|l|l|l|l|l|}
\hline $\begin{array}{c}\text { Sl. } \\
\text { No. }\end{array}$ & Name of The Judge & $\begin{array}{c}\text { Source of } \\
\text { Recruitment }\end{array}$ & $\begin{array}{c}\text { Date of } \\
\text { Appointment } \\
\text { as Addl. Judge }\end{array}$ & $\begin{array}{c}\text { Date of } \\
\text { Appointment } \\
\text { as Pmt. Judge }\end{array}$ & $\begin{array}{c}\text { Date of } \\
\text { Retirement }\end{array}$ \\
\hline 1. & $\begin{array}{l}\text { Kumari Javalakar } \\
\text { Uma Devi (AP) }\end{array}$ & Service & & $17 / 01 / 2017$ & $25 / 09 / 2021$ \\
\hline 2. & $\begin{array}{l}\text { Smt. Telaprolu } \\
\text { Rajani (AP) }\end{array}$ & Service & & $17 / 01 / 2017$ & $05 / 11 / 2020$ \\
\hline 3. & $\begin{array}{l}\text { Smt. Kongara Vijaya } \\
\text { Lakshmi (AP) }\end{array}$ & Bar & & $21 / 09 / 2017$ & $19 / 09 / 2022$ \\
\hline
\end{tabular}

\section{Calcutta High Court}

(List of Female Judges Arranged According to Date of Initial Appointment)

Table 6: projects the cumulative number of female judges at 'Calcutta High Court' as 'Three' in

\begin{tabular}{|l|l|l|l|l|l|}
\hline $\begin{array}{c}\text { Sl. } \\
\text { No. }\end{array}$ & Name of the judge & $\begin{array}{c}\text { Source of } \\
\text { recruitment }\end{array}$ & $\begin{array}{c}\text { Date of } \\
\text { appointment } \\
\text { as addl. Judge }\end{array}$ & $\begin{array}{c}\text { Date of } \\
\text { appointment } \\
\text { as pmt. Judge }\end{array}$ & $\begin{array}{c}\text { Date of } \\
\text { retirement }\end{array}$ \\
\hline 1. & Smt. Nadira Patherya & Bar & -- & $22 / 06 / 2006$ & $18 / 11 / 2018$ \\
\hline 2. & $\begin{array}{l}\text { Smt. Samapti } \\
\text { Chatterjee }\end{array}$ & Bar & $30 / 10 / 2013$ & $14 / 03 / 2016$ & $12 / 12 / 2020$ \\
\hline 3. & Miss Asha Arora & Service & $30 / 03 / 2015$ & $06 / 10 / 2016$ & $01 / 10 / 2019$ \\
\hline
\end{tabular}

\section{Additional Judges}

Table 7: projects the cumulative number of female additional judges at 'Calcutta High Court' as 'Three' in figure. ${ }^{9}$

\begin{tabular}{|l|l|l|l|l|}
\hline $\begin{array}{c}\text { Sl. } \\
\text { No. }\end{array}$ & \multicolumn{1}{|c|}{ Name of the judge } & $\begin{array}{c}\text { Source of } \\
\text { recruitment }\end{array}$ & $\begin{array}{c}\text { Date of appointment } \\
\text { as pmt. Judge }\end{array}$ & $\begin{array}{c}\text { Date of } \\
\text { retirement }\end{array}$ \\
\hline 1. & Smt. Moushumi Bhattacharya & Bar & $21 / 09 / 2017$ & $20 / 09 / 2019$ \\
\hline 2. & Smt. Shampa Sarkar & Bar & $12 / 03 / 2018$ & $11 / 03 / 2020$ \\
\hline 3. & Smt. Amrita Sinha & Bar & $02 / 05 / 2018$ & $01 / 05 / 2020$ \\
\hline
\end{tabular}




\section{Judges Transferred from the Calcutta High Court}

Table 8: projects the cumulative number of female judges at 'Calcutta High Court' as 'Eight' in figure. ${ }^{10}$

\begin{tabular}{|c|l|l|l|l|l|}
\hline $\begin{array}{r}\text { Sl } \\
\text { no. }\end{array}$ & $\begin{array}{l}\text { Name of the } \\
\text { judge }\end{array}$ & $\begin{array}{c}\text { Date of appointment } \\
\text { as addl. Judge }\end{array}$ & $\begin{array}{c}\text { Date of appointment } \\
\text { as pmt. Judge }\end{array}$ & $\begin{array}{c}\text { Date of } \\
\text { retirement }\end{array}$ & Remarks \\
\hline 1. & $\begin{array}{l}\text { Kumari } \\
\text { Indira } \\
\text { Banerjee }\end{array}$ & Bar & $05 / 02 / 2002$ & $23 / 09 / 2019$ & $\begin{array}{l}\text { CJ, } \\
\text { Madras }\end{array}$ \\
\hline
\end{tabular}

\section{Bombay High Court}

(List of Female Judges Arranged According to Date of Initial Appointment)

Table 9: projects the cumulative number of female judges at 'Bombay High Court' as 'Seven' in figure. ${ }^{11}$

\begin{tabular}{|l|l|l|l|l|l|}
\hline $\begin{array}{c}\text { Sl. } \\
\text { No. }\end{array}$ & \multicolumn{1}{|c|}{ Name of the judge } & $\begin{array}{c}\text { Source of } \\
\text { recruitment }\end{array}$ & $\begin{array}{c}\text { Date of } \\
\text { appointment } \\
\text { as addl. Judge }\end{array}$ & $\begin{array}{c}\text { Date of } \\
\text { appointment } \\
\text { as pmt. Judge }\end{array}$ & $\begin{array}{c}\text { Date of } \\
\text { retirement }\end{array}$ \\
\hline 1. & $\begin{array}{l}\text { Smt. Mridula R. } \\
\text { Bhatkar }\end{array}$ & Service & $10 / 02 / 2009$ & $23 / 12 / 2011$ & $27 / 05 / 2019$ \\
\hline 2. & $\begin{array}{l}\text { Smt. Sadhana Sanjay } \\
\text { Jadhav }\end{array}$ & Bar & $23 / 01 / 2012$ & $16 / 12 / 2013$ & $13 / 06 / 2022$ \\
\hline 3. & $\begin{array}{l}\text { Smt. Revati Prashant } \\
\text { Mohite Dere }\end{array}$ & Bar & $21 / 06 / 2013$ & $02 / 03 / 2016$ & $16 / 04 / 2027$ \\
\hline 4. & $\begin{array}{l}\text { Smt. Anuja } \\
\text { Prabhudessai }\end{array}$ & $\begin{array}{l}\text { Service } \\
{[\text { Goa] }}\end{array}$ & $03 / 03 / 2014$ & $02 / 03 / 2016$ & $07 / 02 / 2024$ \\
\hline 5. & $\begin{array}{l}\text { Dr. (Smt.) Shalini } \\
\text { Shashank Phansalkar - }\end{array}$ & Service & $01 / 01 / 2015$ & $17 / 11 / 2016$ & $05 / 02 / 2019$ \\
\hline Joshi & $\begin{array}{l}\text { Smt. Swapna Sanjiv } \\
\text { Joshi }\end{array}$ & Service & $28 / 03 / 2016$ & $13 / 03 / 2018$ & $25 / 08 / 2021$ \\
\hline 7. & $\begin{array}{l}\text { Kumari Nutan D. } \\
\text { Sardessai }\end{array}$ & $\begin{array}{l}\text { Service } \\
{[\text { Goa] }}\end{array}$ & $28 / 03 / 2016$ & $13 / 03 / 2018$ & $18 / 08 / 2020$ \\
\hline
\end{tabular}

\section{Additional Judges}

Table 10: projects the cumulative number of additional female judges at 'Calcutta High Court' as 'Two' in figures. ${ }^{12}$

\begin{tabular}{|l|l|l|l|l|}
\hline $\begin{array}{c}\text { Sl. } \\
\text { No. }\end{array}$ & \multicolumn{1}{|c|}{ Name of the judge } & \multicolumn{1}{|c|}{$\begin{array}{c}\text { Source of } \\
\text { recruitment }\end{array}$} & $\begin{array}{c}\text { Date of appointment } \\
\text { as addl. Judge }\end{array}$ & $\begin{array}{c}\text { Date of } \\
\text { retirement }\end{array}$ \\
\hline 1. & Smt. Bharati Harish Dangre & Bar & $05 / 06 / 2017$ & $04 / 06 / 2019$ \\
\hline 2. & $\begin{array}{l}\text { Smt. Vibha Vasant } \\
\text { Kankanwadi }\end{array}$ & Service & $05 / 06 / 2017$ & $04 / 06 / 2019$ \\
\hline
\end{tabular}




\section{Chhattisgarh High Court}

(List of Female Judges Arranged According to Date of Initial Appointment)

\section{Additional Judges}

Table 11: projects the cumulative number of additional female judges at 'Chhattisgarh High Court' as 'Two' in figures ${ }^{13}$

\begin{tabular}{|l|l|l|l|l|l|}
\hline $\begin{array}{c}\text { Sl. } \\
\text { No. }\end{array}$ & Name of the judge & Date of birth & $\begin{array}{c}\text { Source of } \\
\text { recruitment }\end{array}$ & $\begin{array}{c}\text { Date of initial } \\
\text { appointment }\end{array}$ & $\begin{array}{c}\text { Date of } \\
\text { retirement }\end{array}$ \\
\hline $\mathbf{1}$ & $\begin{array}{l}\text { Smt. Vimla singh } \\
\text { kapoor }\end{array}$ & $16 / 11 / 1959$ & Service & $18 / 06 / 2018$ & $17 / 06 / 2020$ \\
\hline $\mathbf{2}$ & Smt. Rajani dubey & $30 / 06 / 1964$ & Service & $18 / 06 / 2018$ & $17 / 06 / 2020$ \\
\hline
\end{tabular}

\section{Delhi High Court}

(List of Female Judges Arranged According to Date of Initial Appointment)

Table 12: projects the cumulative number of female judges at 'Delhi High Court' as 'Eight' in

\begin{tabular}{|c|c|c|c|c|c|}
\hline $\begin{array}{l}\text { Sl. } \\
\text { No. }\end{array}$ & $\begin{array}{l}\text { Name of the } \\
\text { judge }\end{array}$ & $\begin{array}{c}\text { Source of } \\
\text { recruitment }\end{array}$ & $\begin{array}{c}\text { Date of } \\
\text { appointment } \\
\text { as addl. Judge }\end{array}$ & $\begin{array}{c}\text { Date of } \\
\text { appointment as } \\
\text { pmt. Judge } \\
\end{array}$ & $\begin{array}{c}\text { Date of } \\
\text { retirement }\end{array}$ \\
\hline 1 & Kumari gita mittal & Bar & $16 / 07 / 2004$ & $20 / 02 / 2006$ & $08 / 12 / 2020$ \\
\hline 2 & Kumari hima kohli & Bar & $29 / 05 / 2006$ & $29 / 08 / 2007$ & $01 / 09 / 2021$ \\
\hline 3 & Ms. Mukta gupta & Bar & $23 / 10 / 2009$ & $29 / 05 / 2014$ & $27 / 06 / 2023$ \\
\hline 4 & $\begin{array}{l}\text { Shrimati pratibha } \\
\text { rani }\end{array}$ & Service & $17 / 10 / 2011$ & $16 / 10 / 2014$ & $24 / 08 / 2018$ \\
\hline 5. & $\begin{array}{l}\text { Smt. Sangita } \\
\text { dhingra sehgal }\end{array}$ & Service & $15 / 12 / 2014$ & $02 / 06 / 2016$ & $19 / 06 / 2020$ \\
\hline 6. & Smt. Anu malhotra & Service & -- & $08 / 11 / 2016$ & $26 / 11 / 2022$ \\
\hline 7. & $\begin{array}{l}\text { Smt. Rekha palli } \\
\text { bar }\end{array}$ & Bar & -- & $15 / 05 / 2017$ & $08 / 03 / 2025$ \\
\hline 8. & $\begin{array}{l}\text { Smt. Prathiba } \\
\text { m.singh }\end{array}$ & Bar & -- & $15 / 05 / 2017$ & $19 / 07 / 2030$ \\
\hline
\end{tabular}

\section{Gauhati High Court}

(List of Female Judges Arranged According to Date of Initial Appointment)

Table 13: projects the cumulative number of female judges at 'Gauhati High Court' as 'One' in figure. ${ }^{15}$

\begin{tabular}{|c|l|l|l|c|}
\hline Sl. No. & \multicolumn{1}{|c|}{ Name of the judge } & $\begin{array}{c}\text { Source of } \\
\text { recruitment }\end{array}$ & $\begin{array}{c}\text { Date of initial } \\
\text { appointment }\end{array}$ & $\begin{array}{c}\text { Date of } \\
\text { retirement }\end{array}$ \\
\hline 1. & Smt. Rumi kumari phukan & Service & $07 / 01 / 2015$ & $06 / 01 / 2019$ \\
\hline
\end{tabular}




\section{Gujarat High Court}

(List of Female Judges Arranged According to Date of Initial Appointment)

Table 14: projects the cumulative number of female judges at 'Gujarat High Court' as 'Three' in

\begin{tabular}{|l|l|l|l|l|l|}
\hline $\begin{array}{c}\text { Sl. } \\
\text { No. }\end{array}$ & Name of The judge & $\begin{array}{c}\text { Source of } \\
\text { recruitment }\end{array}$ & $\begin{array}{c}\text { Date of } \\
\text { appointment as } \\
\text { addl. judge }\end{array}$ & $\begin{array}{c}\text { Date of } \\
\text { appointment } \\
\text { as pmt. judge }\end{array}$ & $\begin{array}{c}\text { Date of } \\
\text { retirement }\end{array}$ \\
\hline 1. & Smt.H.N.Devani & Bar & $08 / 10 / 2004$ & $09 / 08 / 2007$ & $26 / 03 / 2020$ \\
\hline 2. & $\begin{array}{l}\text { Miss Bela } \\
\text { Mandhurya Trivedi }\end{array}$ & Service & $17 / 02 / 2011$ & $06 / 02 / 2013$ & $09 / 06 / 2022$ \\
\hline 3. & $\begin{array}{l}\text { Miss Sonia Giridhar } \\
\text { Gokani }\end{array}$ & Service & $17 / 02 / 2011$ & $28 / 01 / 2013$ & $25 / 02 / 2023$ \\
\hline
\end{tabular}

\section{Patna High Court}

(List of Female Judges Arranged According to Date of Initial Appointment)

Table 15: projects the cumulative number of female judges at 'Patna High Court' as 'Two' in figures. ${ }^{17}$

\begin{tabular}{|l|l|l|l|l|l|}
\hline $\begin{array}{c}\text { Sl. } \\
\text { No. }\end{array}$ & \multicolumn{1}{|c|}{ Name of the judge } & $\begin{array}{c}\text { Source of } \\
\text { recruitment }\end{array}$ & $\begin{array}{c}\text { Date of } \\
\text { appointment } \\
\text { as addl. Judge }\end{array}$ & $\begin{array}{c}\text { Date of } \\
\text { appointment } \\
\text { as pmt. Judge }\end{array}$ & $\begin{array}{c}\text { Date of } \\
\text { retirement }\end{array}$ \\
\hline 1. & Smt. Anjana Mishra & Bar & $15 / 05 / 2014$ & $20 / 04 / 2016$ & $29 / 02 / 2020$ \\
\hline 2. & Smt. Nilu Agrawal & Bar & $15 / 04 / 2015$ & $20 / 04 / 2016$ & $21 / 06 / 2019$ \\
\hline
\end{tabular}

\section{Punjab \& Haryana High Court}

(List of Female Judges Arranged According to Date of Initial Appointment)

Table 16: projects the cumulative number of female judges at 'Punjab and Haryana High Court' as 'Five' in figures. ${ }^{18}$

\begin{tabular}{|l|l|l|l|l|l|}
\hline $\begin{array}{c}\text { Sl. } \\
\text { No. }\end{array}$ & \multicolumn{1}{|c|}{ Name of the judge } & $\begin{array}{c}\text { Source of } \\
\text { recruitment }\end{array}$ & $\begin{array}{c}\text { Date of } \\
\text { appointment } \\
\text { as addl. Judge }\end{array}$ & $\begin{array}{c}\text { Date of } \\
\text { appointment } \\
\text { as pmt. Judge }\end{array}$ & $\begin{array}{c}\text { Date of } \\
\text { retirement }\end{array}$ \\
\hline 1. & $\begin{array}{l}\text { Smt. Daya chaudhary } \\
{[\mathrm{h}]}\end{array}$ & Bar & $05 / 12 / 2007$ & $28 / 11 / 2009$ & $09 / 01 / 2021$ \\
\hline 2. & Kumari ritu bahri [h] & Bar & $16 / 08 / 2010$ & $23 / 02 / 2012$ & $10 / 10 / 2024$ \\
\hline 3. & Mrs. Rekha mittal [p] & Service & $15 / 06 / 2012$ & $19 / 12 / 2014$ & $16 / 01 / 2021$ \\
\hline 4. & Smt. Lisa gill [p] & Bar & $31 / 03 / 2014$ & $19 / 12 / 2014$ & $16 / 11 / 2028$ \\
\hline 5. & Miss jaishree thakur [p] & Bar & $25 / 09 / 2014$ & $20 / 05 / 2016$ & $23 / 07 / 2023$ \\
\hline
\end{tabular}




\section{Judges Transferred from The Punjab \& Haryana High Court}

(List of Female Judges Arranged According to Date of Initial Appointment)

Table 17: projects the cumulative number of female judges transferred from 'Punjab and Haryana High Court' as 'Two' in figures. ${ }^{19}$

\begin{tabular}{|l|l|l|l|l|l|}
\hline $\begin{array}{c}\text { Sl. } \\
\text { No. }\end{array}$ & Name of the judge & $\begin{array}{c}\text { Source of } \\
\text { recruitment }\end{array}$ & $\begin{array}{c}\text { Date of } \\
\text { appointment } \\
\text { as addl. Judge }\end{array}$ & $\begin{array}{c}\text { Date of } \\
\text { appointment } \\
\text { as pmt. Judge }\end{array}$ & $\begin{array}{c}\text { Date of } \\
\text { retirement }\end{array}$ \\
\hline 1. & Smt. Sabina [p] & Service & $12 / 03 / 2008$ & $23 / 02 / 2010$ & $\begin{array}{l}19 / 04 / 2023 \\
\text { Transfer to } \\
\text { rajasthan }\end{array}$ \\
\hline 2. & Nirmaljit kaur [p] & Bar & $10 / 07 / 2008$ & $29 / 06 / 2012$ & $\begin{array}{l}27 / 01 / 2021 \\
\text { Transfer to } \\
\text { rajasthan }\end{array}$ \\
\hline
\end{tabular}

\section{Rajasthan High Court}

(List of Female Judges Arranged According to Date of Initial Appointment)

Table 18: projects the cumulative number of female judges 'Rajasthan High Court' as 'Two' in figures. ${ }^{20}$

\begin{tabular}{|l|l|l|l|l|l|}
\hline $\begin{array}{c}\text { Sl. } \\
\text { No. }\end{array}$ & Name of the judge & $\begin{array}{c}\text { Source of } \\
\text { recruitment }\end{array}$ & $\begin{array}{c}\text { Date of } \\
\text { appointment } \\
\text { as addl. Judge }\end{array}$ & $\begin{array}{c}\text { Date of } \\
\text { appointment } \\
\text { as pmt. Judge }\end{array}$ & $\begin{array}{c}\text { Date of } \\
\text { retirement }\end{array}$ \\
\hline 1. & Smt. Sabina [p] & Service & $12 / 03 / 2008$ & $23 / 02 / 2010$ & $\begin{array}{l}19 / 04 / 2023 \\
\text { Joined on } \\
11 / 04 / 2016 \\
\text { [phc: } \mathrm{p} \& \mathrm{~h}]\end{array}$ \\
\hline 2. & Nirmaljit kaur [p] & Bar & $10 / 07 / 2008$ & $29 / 06 / 2012$ & $\begin{array}{l}27 / 01 / 2021 \\
\text { Joined on } \\
09 / 07 / 2012 \\
\text { [phc: } \mathrm{p} \& \mathrm{~h}]\end{array}$ \\
\hline
\end{tabular}

\section{Sikkim High Court}

(List of Female Judges Arranged According to Date of Initial Appointment)

Table 19: projects the cumulative number of female judges 'Sikkim High Court' as 'One' in figure. $^{21}$

\begin{tabular}{|l|l|l|l|l|l|}
\hline $\begin{array}{c}\text { Sl. } \\
\text { No. }\end{array}$ & Name of The Judge & $\begin{array}{c}\text { Source of } \\
\text { Recruitment }\end{array}$ & $\begin{array}{c}\text { Date of } \\
\text { Appointment } \\
\text { as Addl. Judge }\end{array}$ & $\begin{array}{c}\text { Date of } \\
\text { Appointment } \\
\text { as Pmt. Judge }\end{array}$ & $\begin{array}{c}\text { Date of } \\
\text { Retirement }\end{array}$ \\
\hline 1. & $\begin{array}{l}\text { Smt. Meenakshi } \\
\text { Madan Rai }\end{array}$ & Service & -- & $15 / 04 / 2015$ & $11 / 07 / 2026$ \\
\hline
\end{tabular}




\section{Comparative Study of Reports of Law Ministry}

\subsection{Numerical Evaluation}

The numerical denominations have showed such shrinking proposition of women holding benches in the revealed data, as the highest being at the Delhi High Court with 'Eight' female judges and the second-High Court of India, Bombay High Court of India with 'Seven' female judges.

There are still many High Courts which have 'Three' female judges at Calcutta High Court and Gujarat High Court.

The judges at Rajasthan High Court, Patna High Court and Chhattisgarh High Court remain at a much lower figurine 'Two.'

The lowest women held position remain at Sikkim High Court and Guwahati High Court, with numerical denomination of 'One' only.

The numerical presentation revealed in the aforementioned Tables very clearly establishes the fact that women have very less hold on the benches of Indian Judiciary.

The reasons behind such less women figure in Indian Judiciary has been evaluated in the subsequent Chapter of the same.

\section{Importance of Women in Judiciary}

\subsection{Vidhi Legal Policy}

A current study by Vidhi legal policy, deliberated the proportion of women judges to men in the lower judiciary and broke its verdicts down by state and district. The results paint a troubling picture: women comprise an abysmally low $28 \%$ lower court judges in India.

The report argues that it is the presence of women judges is important because of several reasons.

- It provides decision making power to units of the society which were disenfranchised before.

- An assorted bench is essential for a fair and impartial judiciary.

- A miscellany of viewpoints makes courts more representative and democratically legitimate, and enables them to understand the implications of their rulings on the real world.

- Inclusion of women judges allows for other women ambitious for a career in law to access mentorship.

- It allows women looking for justice to face less stigma, especially when reporting violence and abuse.

- Despite these reasons, the researchers note that women's representation in all of judiciary, is in a sorry state. For illustration, the Supreme Court has only ever has seven women judges. And India's 24 High Courts have only a little over $10 \%$ of women judges. 
“The District Courts and the courts below them comprise the 'lower' or 'subordinate' judiciary. These courts lie under the administrative control of High Courts. Each judicial district in India has one District Court, below which lie civil and criminal courts of original jurisdiction," the study notes, and finds that $71 \%$ judges in the subordinate judiciary across India are male.

\subsection{Appallingly Low Number of Women in Lower Judiciary}

The southern states of Andhra Pradesh and Telangana had 37\% and 44\% women judges respectively. Meanwhile Kerala had $67 \%$ and Karnataka, $70 \%$ judges who were men. Tamil Nadu had 607 and 357 male and female judges respectively, not including 12 judges whose information was unavailable.

The smaller states, Goa, Meghalaya and Sikkim, fared relatively well with 66\% (29), 74\% (31) and $65 \%$ (11) judges who were women - 103 in total.

The report suggests that breaking down data into these numbers can help zero in on factors which affect gender composition and may help policy makers.

Researchers also note that unlike the higher judiciary, some states have provided a quota for women in the lower judiciary, such as Andhra Pradesh, Assam, Bihar, Chhattisgarh, Jharkhand, Karnataka, Odisha, Rajasthan, Tamil Nadu, Telangana. The quota ranges between 30\% and 35\% and women are appointed to these positions through direct recruitment. ${ }^{22}$

\section{Evaluation of Reasons for Less Women in Judiciary}

\subsection{Biases in Promotion Process}

One of the reasons why women are there are so few women in the lower judiciary, and also higher judiciary, is because of the low numbers of the previous years.

"If there were fewer female Civil Judges (Junior Division) in 1995, for instance, than now, fewer women judges would currently occupy higher posts in the lower judiciary, since higher posts are mostly filled through promotion from Civil Judges (Junior Division)," the study explains.

It also points to potential bias in promotional processes. "Given that men and women are equally meritorious, in the absence of discrimination, one would assume that the proportion of women judges will remain the same from the lowest to the higher tiers, for any given batch of judicial officers. While the historical data required to assess this is not readily available, several women judges and lawyers have reported discrimination in appointment and promotions."

To demonstrate, here's are some tables from the study which shows how the number of women judges decreases as one moves higher up in the judiciary.

\subsection{The Number Game}

Another interesting correlation drawn is that the numbers depend on how many women appear for judicial exams, which is linked to how many graduate as lawyers, which in turn depends on the 
number of women who choose to study law. This is further taken down to the number of women able to complete primary and secondary education, and ultimately, the relationship with the sex ratio in the state or district.

However, this is not a fool proof chain. For instance, while the study found a "moderate correlation of 0.44 between sex ratio and the representation of women in the lower judiciary", there were also exceptions. "Although Kerala has the best sex ratio amongst all states, only 33\% of women are part of its lower judiciary. States such as Punjab, Sikkim, Meghalaya and Tamil Nadu, on the other hand, have a lower sex ratio than Kerala but have a higher representation of women judges in lower courts," the study points out.

\subsection{Discrimination}

While there is lack of quantifiable data in this regard, a number of lawyers - from Indira Jaising to Meenakshi Arora - have talked about discrimination meted out to women litigators. They have also spoken about the pervasive 'old boys' club mentality, which makes it harder for women to attain judicial positions.

These biases are also found in clients, as well as infrastructure and employment benefits for women in judiciary.

Incentives and work environments provided to women in the judiciary are also important factors. "Sexual harassment and the lack of supportive infrastructure, from toilets to maternity leave, also contribute to a high attrition rate amongst women lawyers, with many preferring to join the corporate sector instead. All these factors come together to result in disproportionately low women bar appointees to the bench. For instance, in its 68 years of existence, the Supreme Court has only seen one woman elevated from the bar to the bench, as recently as January 2018," researchers say. Further, women who do make it to the judiciary tend to be judged more harshly. The study quotes an unnamed retired woman Supreme Court judge who said that her judgments were accepted only when they were backed by a larger bench. Another woman judge said that a male judge would always question her inference on issues. ${ }^{23}$

\section{A Silver Lining}

Underlining the fact that there is need for more rigorous data collection to address the issue, the study ends on a positive note. It points out some recent advances which seem to indicate that the tide may be turning, slowly. "In 2017, for the first time, all four High Courts of Delhi, Calcutta, Bombay and Madras were headed by women Chief Justices," it says.

Many leaders and members of judiciary have also been voicing the need for equitable gender representation in the judiciary. For instance, President Ram Nath Kovind recently acknowledged this gender imbalance and in his speech on National Law Day, and urged political leaders to allocate quotas for women in the judiciary. 


\section{Conclusion and Suggestion}

Women are not born, but made. What better than India to exemplify this statement by Simone de Beauvoir. With the whole world celebrating International Women's Day with great pomp and show, it would be only apt to analyze the position and space Indian women occupy today, and comparing it to the time 70 years ago when the country had just gained independence. With women participating in nationalist movements, to being pushed into the domestic household space, to their resurgence as super-women today, women in our country have seen it all.

There have been innumerable debates about gender in India over the years. Much of it includes women's positing in society, their education, health, economic position, gender equality etc. What one can conclude from such discussions is that women have always held a certain paradoxical position in our developing country.

They were relegated to the household, and made to submit to the male-dominated patriarchal society, as has always been prevalent in our country. Indian women, who fought as equals with men in the nationalist struggle, were not given that free public space anymore. They became homemakers, and were mainly meant to build a strong home to support their men who were to build the newly independent country. Women were reduced to being second class citizens. The national female literacy rate was an alarmingly low 8.6\%. The Gross Enrolment Ratio (GER) for girls was $24.8 \%$ at primary level and $4.6 \%$ at the upper primary level (in the 11-14 years age group). There existed insoluble social and cultural barriers to education of women and access to organized schooling.

\section{Acknowledgements}

Many working papers have been proposed to establish the fact of the trending Euthanasia Laws in the land. In this research work, the work of the following journals have been taken in account to extract the aim of my research paper. The following pivotal research papers are henceforth acknowledged:

- 'Concept of Euthanasia in India - A Socio- Legal analysis', By: Dr Sanjeev Kumar Tiwari, Associate Professor, Law Dept, Burdwan University \& Ambalika Karmakar, Assistant Professor, Haldia law college- International Journal of Law and Legal Jurisprudence Studies: ISSN:2348-8212 Volume 2 Issue 3

- 'Euthanasia - The "Good Death" Controversy in Humans and Animals' Edited by Josef Kuře- INTECH Open Access Publisher.

- 'Euthanasia'- Routledge Taylor and Francis Group

- 'Aruna Shanbaug V/s. Union of India: Case Comment' By Tanya Sarkar- International Journal of Legal Insight Volume I, Issue 3| ISSN: 2456-3595

\section{References}

[1] 'Women account for less than $28 \%$ of total judges in country' available at "https://timesofindia.indiatimes.com/india/women-account-for./.html" accessed on $30^{\text {th }}$ March, 2018

[2] 'List of High Court Judges | Department of Justice | Ministry of Law and Justice' available at "doj.gov.in" accessed on 30 ${ }^{\text {th }}$ March, 2018 
[3] Supra note no. 2

[4] 'WOMEN IN THE INDIAN JUDICIARY-Justice Hima Kohli' available at "https:/ sowlindia.com/upload/SpeechJusticeHimaKohli.pdf/.html" accessed on 30 ${ }^{\text {th }}$ March, 2018

[5] 'List of High Court Judges | Department of Justice | Ministry of Law and Justice' available at "doj.gov.in" accessed on 30 $0^{\text {th }}$ March, 2018

[6] Supra note no. 5

[7] Supra note no. 5

[8] Supra note no. 5

[9] Supra note no. 5

[10] Supra note no. 5

[11] Supra note no. 5

[12] Supra note no. 5

[13] Supra note no. 5

[14] Supra note no. 5

[15] Supra note no. 5

[16] Supra note no. 5

[17] Supra note no. 5

[18] Supra note no. 5

[19] Supra note no. 5

[20] Supra note no. 5

[21] Supra note no. 5

[22] ' 67 years of Supreme Court, 6 women judges - Livemint' available at "https://www.livemint.com/.html" accessed on 30 $30^{\text {th }}$ March, 2018

[23] 'Missing Gender Diversity in the Indian Judiciary - Factly' available at 'https://factly.in/missinggender-diversity-indian-judiciary/' accessed on $30^{\text {th }}$ March, 2018.

*Corresponding author.

E-mail address: bipashabandopadhyay@ gmail.com 